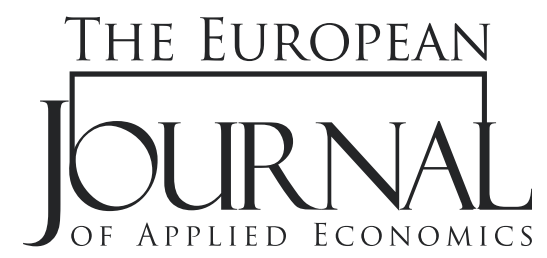

\title{
MEASURING DISTRIBUTION OF INTELLECTUAL CAPITAL COMPONENTS CONTRIBUTION: FRENCH CONTEXT
}

\author{
Endre Pap, Miloš Petković*, Ana Simićević \\ Singidunum University, \\ Belgrade, Serbia
}

\begin{abstract}
:
In this paper the contribution of intellectual capital components in the overall intellectual capital value is investigated. This paper adopted quantitative statistical methods Lambda phase measurement and Shapley's value on the sample of 498 French companies in the period of 2008 to 2016 in order to estimate the highest and lowest contributions of intellectual capital components. For the purpose of the study, the official financial information from the companies' annual reports were taken from the financial database "Point Risk". The paper concentrates on two out of three intellectual capital components: structural and customer capital components. By the Shapley's value final result, the customer capital component, which represents company's commercial activities with the coefficient of 0.29911 , is of greatest importance. On the other side, the lowest importance belongs to the structural capital component that represents value coming from research and development expenses with the coefficient of 0.07463 This study contributes to the management sciences literature byexamining distribution of contribution of two intellectual capital components in the annual reports of French companies.
\end{abstract}

\section{Article info:}

Received: October 1, 2020

Correction: November 23, 2020

Accepted: December 21, 2020

\section{INTRODUCTION}

In the knowledge-based economy, it is not enough just to take the traditional and financial measures of a company into account, but it is important to find a way to recognize intellectual capital as well. Traditional measures are highly unsuitable mainly because they are based on conventional accounting principles. This is the biggest challenge for companies, because companies must measure these values consistently and systematically over time (Belo et al., 2014). The limits in the valuation process are no longer focused on the production of physical products or providing services. Instead, they are focused on the creation of new innovations and ideas (Mura et al., 2012), because the main value creators are intellectual investment values (Zéghal \& Maaloul, 2011). 
The concept of intellectual capital was revealed for the first time in 1969 by Kenneth Galbraith. Kenneth Galbraith wrote a letter to the economist, Michael Kalecki, where he stated, "I wonder if you realize how much those of us around the world have owed to the intellectual capital you have provided over these past decades." (Hudson, 1993).

The interest in studying this topic lies in the fact that employees' competences and human capital are the main drivers of companies' competitiveness in the modern economy (Radivojevic et al., 2019). Investing in human capital influences positively on company's productivity with precise measurements (McGrattan, 2020). Intellectual capital plays an important role in a company's final success (RodriguezCastellanos et al., 2011), but at the same time, in a period of crisis and financial shocks, it enables greater labor market volatility as a response (Lopez and Olivella, 2018).

Intellectual capital as a strategic resource of each company is not a sole thing; it is composed of many interrelated elements that have been continuously cooperated and supported together as a whole (Corrado et al., 2012). Based on the available literature, intellectual capital is classified into three components: human capital, structural capital and customer capital (Martínez-Torres, 2006). The competitive advantage of a company lies in the complexity of these components of intellectual capital. Success of a company depends on the strategic management of the selected components of intellectual capital because the investments in intellectual capital are seen as capital expenditures (Piekkola, 2011).

Garanina and Pavlova (2011) prove that a positive interaction between human capital, structural capital and customer capital exists. The interaction between three main components of intellectual capital, human capital, structural capital and customer capital generates benefits to a company. The results of the study of Sumedrea (2013) showed that a company's crisis in development can be exceeded by a company's human and structural capitals. Maditinos et al. (2011) found significant human capital and structural capital efficiency and financial company performance. Diez et al. (2010) tried to examine the influence of human capital and structural capital on the creation of business value of Spanish companies which have 25 or more employees. The study confirmed a positive relationship between the use of human and structural capital and value creation that comes from sales growth.

In an effort to emphasize importance of particular intellectual capital component compared to other two, the purpose of this study is to turn attention to the unique contribution of a total intellectual capital surplus generated by the coalition of all intellectual capital components. A coalition between intellectual capital components obtain certain overall gains from that correlation. Since some components may contribute more to the coalition than others, what final performance should arise in any particular contribution? The question that arises is what is the contribution of each intellectual capital component to the overall intellectual capital value?

Our paper contributes to science by examining which intellectual capital component contributes the most in the sample of French companies, taking into consideration their existing interrelations. In that way, a company will pay attention and invest more in a particular component in order to gain higher benefits in the upcoming future periods. The analysis is composed of 498 French companies over the period of 2008 to 2016 from 34 different industries. In this paper, the following statistical quantitative methods are implemented: Lambda Phase Measurement Method and Shapley's Value Method.

This paper consists of six sections. Section 2 contains the explanation of the history of the intellectual capital components. Section 3 is devoted to the problem of Intellectual Capital of 498 French companies. In Section 4, we explain the methodology used to solve our research question. In Section 5, we apply the presented methodology from Section 4 on the stated problem from Section 3. The last Section 6 is devoted to the discussion of the obtained results. 


\section{HISTORY OF THE PROBLEM OF INTELLECTUAL CAPITAL}

\section{Intellectual Capital Components and Its Interrelations}

Twentieth century is a century of ideas, knowledge, innovations, information and changes. Industries that provide services expanded radically. Simultaneously, the financial market became influential in the global market, so "intellectual capital" obtained a very important role for itself. Market value of a company is composed of total book value, everything that is a company's property and intellectual capital (Ciprian et al., 2012).

The results today must come from the investments made in previous periods (García- Zambrano et al., 2018). If an organization wants to fulfil itsadvanced planned goals, it is not possible without the existence of intellectual capital (Singla, 2020; Sydler et al., 2014).

According to a synthesis from extant literature, intellectual capital is classified into three components (Marr and Moustaghfir, 2005; Martínez-Torres, 2006;):

1) Human Capital - Human capital represents employees' knowledge, competencies and education;

2) Customer Capital - Customer capital represents all relations with customers, suppliers, distributors and other stakeholders. Customer capital is a very important type of intellectual capital for every company, mainly because a company is not an isolated entity. It is an organization that continuously interacts with its business environment. Business environment, together with its customers and clients represents a source of knowledge regarding advantages or disadvantages of a company's products or services, new ideas, organizational practices, etc.;

3) Structural Capital - Structural capital refers to organizational systems, culture, practices, processes and business routines (Marr and Moustaghfir, 2005). A company exists because of a combination of employees' competences and internal structure and organization (Hashim et al., 2015). Based on the literature, intellectual capital components and its investments are linked to value factors (Dumay, 2012).

Different authors prove highly positive interrelations between intellectual capital components. Ognjanovic (2017) proved a strong and positive relationship between the observed intellectual capital components based on the combined factor, analysis and structural equation study of 44 hotel companies in Serbia. The strongest relationship is observed between customer capital and structural capital. Authors Ulubeyli and Yorulmaz (2019) proved that human capital and structural capital together have a strong impact on the financial performance in a highly innovative industry such as consulting industry. However, the relational capital may not lead to the same result on the financial result. The study published by Molodchik et al. (2012) examined the interrelation between intellectual capital components. From those interrelations, further improvements of company's competitive advantage were produced, which increased company's value. Many authors proved a positive and significantly strong relationship between intellectual capital components and financial performance (Chang, 2013; Díaz- Fernández et al., 2015; Pucci et al., 2015; Sharabati et al., 2010; Soewarno and Tjahjadi, 2020; Tanideh, S., 2013). Jensen et al. (2020) proved that between intellectual stimulation and financial performance indicators exists a strong and positive relationship.

On the other side, relationship between intellectual capital components and final results were not always positive (Chu et al., 2011; Mehralian et al., 2012). 


\section{INTELLECTUAL CAPITAL OF 498 FRENCH COMPANIES}

\section{Data Sample Explanation}

The study is focused on the financial information gathered by the financial database "Point Risk". It comprises of financial data from the financial statements of French companies during the period of 2008 to 2016. Both high-technology and low-technology companies are included in the sample. Divided into these two industrial groups, companies belong to 34 different industries that proves heterogeneity of the observed sample. The classification of industries is proposed by Francis and Schipper (1999).

In the research model, the initial number of companies was 1,990. After detailed investigation, 1,195 companies did not have complete required financial information. Furthermore, 297 companies are mentioned more than once in the database. The final number of companies observed and finally tested is 498 .

Table 1: Number of companies included in the research model

\begin{tabular}{lc}
\hline & Number of Companies \\
\hline Starting Number, Observed & 1,990 \\
\hline Missing Data Companies & 1,195 \\
\hline Repeating Companies & 297 \\
\hline Final Number of Companies & $\mathbf{4 9 8}$ \\
\hline
\end{tabular}

In Table 2 below, the structure of the total number of selected companies in the sample is presented. As we can conclude from the sample, the largest number of companies is from the Low Technology Industry - Miscellaneous Manufacturing Industries - 89, followed by those from High Technology, listed chronologically, Computer Programming, Software, Data Processing, Research, Development, Testing Services, Drugs and Electrical Apparatus, 81, 44, 38 and 35. In total, there are 241 companies that belong to the High Technology industries, and 257 companies that belong to the Low Technology industries. The percentage between the High Technology and Low Technology is 48\% and 52\%. 
Table 2: Number of companies per industry in the sample

\begin{tabular}{|c|c|}
\hline Industry & Number of Companies \\
\hline Low Technology - Miscellaneous Manufacturing Industries & 89 \\
\hline High Technology - Computer Programming, Software, Data Processing & 81 \\
\hline High Technology - Research, Development, Testing Services & 44 \\
\hline High Technology - Drugs & 38 \\
\hline High Technology - Electrical Industrial Apparatus & 35 \\
\hline Low Technology - General Industrial Machinery and Equipment & 31 \\
\hline Low Technology - Agricultural Products & 26 \\
\hline Low Technology - Miscellaneous Plastics Products & 18 \\
\hline Low Technology - Motor Vehicles and Motor Vehicle Equipment & 18 \\
\hline Low Technology - Blast Furnaces and Steel Works & 16 \\
\hline High Technology - Electrical Machinery and Equipment, Excluding Computers & 15 \\
\hline Low Technology - Wood Buildings, Mobile Homes & 14 \\
\hline High Technology - Computer and Office Equipment & 11 \\
\hline Low Technology - Grocery Stores & 10 \\
\hline Low Technology - Textile Mill Products & 9 \\
\hline Low Technology - Lumber and Wood Products, Excluding Furniture & 8 \\
\hline High Technology - Computer Hardware & 6 \\
\hline High Technology - Telephone Communications & 6 \\
\hline High Technology - Electronic Components, Semiconductors & 5 \\
\hline Low Technology - Construction - Special Trade & 5 \\
\hline Low Technology - Trucking, Courier Services, Excluding Air & 5 \\
\hline High Technology - Electrical Transmissions and Distribution Equipment & 4 \\
\hline High Technology - Household Audio, Video Equipment, Audio Receiving & 4 \\
\hline Low Technology - Paper and Allied Products & 4 \\
\hline High Technology - Communication Equipment & 3 \\
\hline High Technology - Electrical Lighting and Wiring Equipment & 3 \\
\hline Low Technology - Dairy Products & 3 \\
\hline Low Technology - Cement Hydraulic & 2 \\
\hline Low Technology - Rubber and Miscellaneous Plastics Products & 2 \\
\hline Low Technology - Scheduled Air Transportation, Air Courier & 1 \\
\hline Low Technology - Water Transportation & 1 \\
\hline Total Number of Companies & 498 \\
\hline
\end{tabular}




\section{METHODS OF LAMBDA MONOTONE MEASURE AND SHAPLEY VALUE}

As an efficient tool for measuring the interaction between elements, monotone measure is defined in the following way, see Pap (1995):

Definition 4.1. Let $X=\left\{\chi_{1}, \chi_{2}, \ldots, \chi_{n}\right\}$ be a fixed set. $P(X)$ is a set of all the subsets of the set $X$. Monotone measure on $X$ is a set function $\mu: P(X) \rightarrow[0.1]$, which satisfies the following conditions:

(i) $\mu(\varnothing)=0, \mu(X)=1$,

(ii) If $A, B \in P(X)$ and $A \subseteq B$, then $\mu(A) \leq \mu(B)$.

In order to determine such a monotone measure, we must find $2^{\mathrm{n}}-2$ of its values, since by Definition 4.1. $\mu(\varnothing)$ and $\mu(X)$ are always equal to zero and one, respectively. It is obvious that such an evaluation process is rather complex, especially in application. In order to reduce the complexity of calculation, $\lambda$-monotone measure $\mu$, which acts as a special kind of monotone measure has been proposed, see Wang and Klir (2009), and Torra et al. (2014).

Definition 4.2. Let $X=\left\{\chi_{1}, \chi_{2}, \ldots, \chi_{n}\right\}$ be a fixed set. Monotone measure $\mu$ on $X$ is called $\lambda$-monotone measure if it satisfies the following condition:

$$
\mu(A \cup B)=\mu(A)+\mu(B)+\lambda \mu(A) \mu(B),
$$

where $\lambda \in(-1, \infty)$, for $\forall A, B \in P(X)$ and $A ! B=\varnothing$.

Theorem 4.1. Let $X=\left\{\chi_{1}, \chi_{2}, \ldots, \chi_{n}\right\}$ be a finite set, and $\mu$ be a $\lambda$-monotone measure on $X$.

Then the following equality holds

$$
\begin{array}{ll}
\mu\left(\bigcup_{i=1}^{\mathrm{n}}\left\{\chi_{i}\right\}\right)= & \\
=\left\{\begin{array}{ll}
\frac{1}{\lambda}\left(\prod_{i=1}^{n}\left[1+\lambda \mu\left(\left\{\chi_{i}\right\}\right)\right]-1\right), & \text { for } \lambda \neq 0 \\
\sum_{i=1}^{n} \mu\left(\left\{\chi_{i}\right\}\right), & \text { for } \lambda=0
\end{array}\right\}
\end{array}
$$

where $\left\{\chi_{i}\right\} \cap\left\{\chi_{j}\right\}=\varnothing$, for each $i, j=1, \ldots, n$ and $i \neq j$.

For a subset $A \in P(X)$ the following holds

$$
\mu(A)=\left\{\begin{array}{ll}
\frac{1}{\lambda}\left(\prod_{i \in A}\left[1+\lambda \mu\left(\left\{\chi_{i}\right\}\right)\right]-1\right), & \text { for } \lambda \neq 0 \\
\sum_{i \in A} \mu\left(\left\{\chi_{i}\right\}\right), & \text { for } \lambda=0
\end{array}\right\}
$$

The value of the parameter $\lambda$ can be determined by applying the above equation. The equation for $X$, since $\mu(X)=1$, reduces on the following equation

$$
\mu+1=\prod_{\mathrm{i}=1}^{\mathrm{n}}\left(1+\lambda \mu\left(\left\{\chi_{i}\right\}\right)\right)
$$


Theorem 4.2. The sign of the parameter $\lambda$ is given by the following conditions

(i) $\lambda>0$, when $\sum_{i=1}^{\mathrm{n}} \mu\left(\left\{\chi_{i}\right\}\right)<\mu(X)$,

(ii) $\lambda=0$, when $\sum_{\mathrm{i}=1}^{\mathrm{n}} \mu\left(\left\{\chi_{i}\right\}\right)=\mu(X)$,

(iii) $-\frac{1}{\mu(X)}<\lambda<0$, when $\sum_{\mathrm{i}=1}^{\mathrm{n}} \mu\left(\left\{\chi_{\mathrm{i}}\right\}\right)>\mu(X)$.

Shapley proposed a coefficient of importance which is called Shapley value (abbreviated to $\varphi_{i}(\mu)$ ), defined it on $X=\left\{\chi_{1}, \chi_{2}, \ldots, \chi_{n}\right\}$ in the following way, see Grabisch (2016):

$$
\varphi_{i}(\mu, X)=\sum_{T \subseteq X\{\{i\}} \frac{(n-t-1) ! t !}{n !}[\mu(T \cup i)-\mu(T)]
$$

where, $t$ is the cardinality of the subset $T$ of the set $X$.

The Shapley value of a particular variable intuitively represents the average change in prediction that occurs in a coalition when joined by a given variable. Based on the previous equation (4), we know that Shapley value is an expected value of the total marginal contribution between elements $i$ and any other coalition. Having in mind the definition of monotone measure, it is easy to notice that $\varphi_{i}(\mu) \geq 0$ and $\sum_{i=1}^{\mathrm{n}} \varphi_{i}(\mu)=1$ for each $i$, which means that $\left\{\varphi_{i}(\mu)\right\}$, is a weight vector, named Shapley value. Specially, when measure $\mu$ is additive, then $\varphi_{i}(\mu)=\mu(i)$, which means that there is no interaction between elements $i$ and any other coalition $T \subseteq X \mid\{i\}$. In this case, Shapley value becomes a traditional weight vector $\omega=\left(\omega_{1}, \omega_{2}, \ldots, \omega_{n}\right)^{T}$, where $\omega_{i}=\mu(i)$. When $\mu$ is not additive, then $\varphi(\mu)>\mu(i)$, which means that there is a complementary interaction between elements $i$ and any other coalition $T \subseteq X \mid\{i\}$.

If $\varphi(\mu)<\mu(i)$ then there is a redundant interaction between elements $i$ and any other coalition $T \subseteq X \mid\{i\}$. Therefore, Shapley's weight not only offers the measure of criteria value, but also maintains their interactive characteristics.

\section{SOLUTION OF THE PROBLEM FROM SECTION 3}

We demonstrate the determination of the parameter formonotone measure for the problem stated in Section 3. The following data are presented in the table:

(a) value of the research asset,

(b) research and development expenditures,

(c) commercial expenses and

(d) sales expenses.

They are compared in this paper by calculating Shapley values for all four variables. 


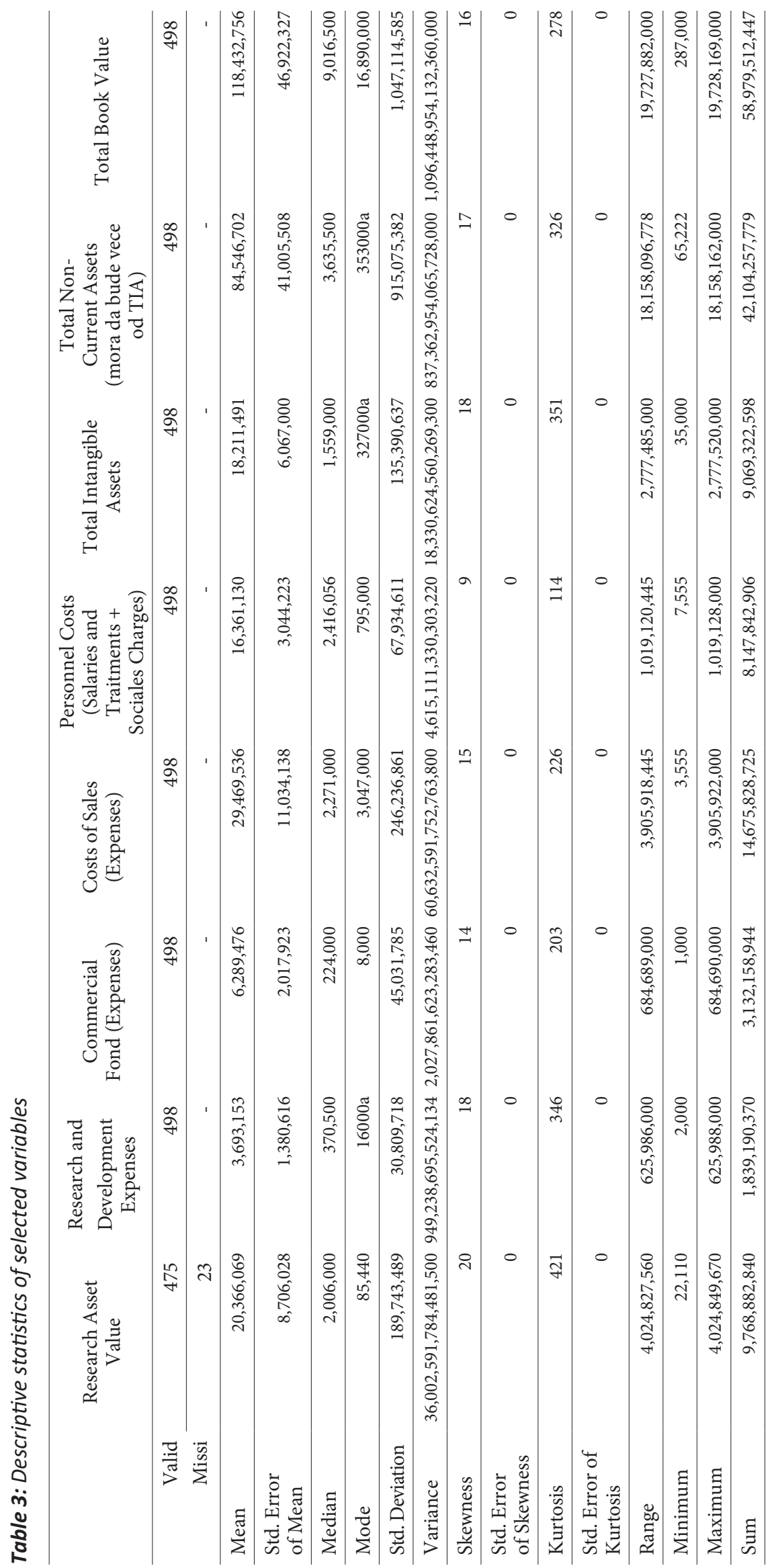


The study is focused on two out of three intellectual capital components, and those are: customer capital and structural capital components.

According to Miles (2011) costs related to marketing and commercial activities represent the customer capital. In order to achieve a better market or financial position, companies strive to attract more and more customers. The study by García-Zambrano et al. (2018) also proved a positive link between the investments in customer capital and Tobin's $Q$ ratio results that resulted in improvement of company's financial performance.

For the purpose of calculating more easily, the set of variables in the table is marked as $X$ and each variable is allocated a letter in the following order $a, b, c, d$.

$X=(a, b, c, d), \mu(X)=1, \mu(\{a\})=0.2037, \mu(\{b\})=0.3693, \mu(\{c\})=0.6289, \mu(\{d\})=0.2947$.

We then 6 use the formula (3) to calculate the parameter $\lambda$. Since $\sum_{i=1}^{6} \mu\left(\left\{\chi_{i}\right\}\right)>\mu(X)$, and based on the Theorem 4.2, we expect for the parameter $\lambda$ that $-1<\lambda<0$. We obtain the following equation:

$$
(1+\lambda \cdot 0,2037) \cdot(1+\lambda \cdot 0,3693) \cdot(1+\lambda \cdot 0,6289) \cdot(1+\lambda \cdot 0,2947)=\lambda+1,
$$

which is transformed into an equation of fourth degree:

$$
\lambda^{4} \cdot 0.0139+\lambda^{3} \cdot 0.1756+\lambda^{2} \cdot 0.7897+\lambda \cdot 0.4966=0 .
$$

We denote $f(\lambda)=\lambda^{4} \cdot 0.0139+\lambda^{3} \cdot 0.1756+\lambda^{2} \cdot 0.7897+\lambda \cdot 0.4966$. Using the halving method, we obtain an approximate solution of the previous equation where the error is lower than $10^{-2}$. The number of steps is determined by the following condition:

$$
\frac{B-A}{2^{n}} \leq 10^{2} \Leftrightarrow n \geq 7
$$

Applying the halving method, we obtain a series of approximations by finding the midpoint of the interval:

$$
\lambda_{1}=\frac{A+B}{2}=\frac{-1+0}{2}=-0.5
$$

Then, using the function sign $\left(f\left(\lambda_{1}\right)>0\right)$ we check, which in half of the interval, is the root of the equation. The same method is repeated on that half of the interval with the new $A$ and $B$. We search for the midpoint of the interval again and we repeat the method 7 times. All the obtained values are given in the following table:

Table 4: Produced values from halving method

\begin{tabular}{ccccc}
\hline $\mathrm{n}$ & $\mathrm{A}$ & $\mathrm{B}$ & $\lambda_{\mathrm{n}}$ & $f\left(\lambda_{\mathrm{n}}\right)$ \\
\hline 1 & -1 & 0 & -0.5 & 0.1439 \\
\hline 2 & -1 & -0.5 & -0.75 & -0.0027 \\
\hline 3 & -0.75 & -0.5 & -0.625 & 0.0682 \\
\hline 4 & -0.75 & -0.625 & -0.6875 & 0.0321 \\
\hline 5 & -0.75 & -0.6875 & -0.71875 & 0.0145 \\
\hline 6 & -0.75 & -0.71875 & -0.734375 & -0.3847 \\
\hline 7 & -0.734375 & -0.71875 & -0.7265625 & \\
\hline
\end{tabular}


Value $\lambda=-0.7265625$ is an approximate solution of the starting equation. Then, based on the formula (1), we calculate the remaining values of the measures on all subsets of the set $X$.

The obtained results are presented below:

$$
\begin{aligned}
& \mu\{\mathrm{a}\}=0.2037 \\
& \mu\{\mathrm{a}, \mathrm{b}\}=0.518343 \\
& \mu\{\mathrm{a}, \mathrm{b}, \mathrm{c}\}=0.910394 \\
& \mu\{\mathrm{a}, \mathrm{b}, \mathrm{c}, \mathrm{d}\}=1.01016 \\
& \mu\{\mathrm{a}, \mathrm{b}, \mathrm{d}\}=0.702057 \\
& \mu\{\mathrm{a}, \mathrm{c}\}=0.739522 \\
& \mu\{\mathrm{a}, \mathrm{c}, \mathrm{d}\}=0.875877 \\
& \mu\{\mathrm{a}, \mathrm{d}\}=0.454784 \\
& \mu\{\mathrm{b}\}=0.3693 \\
& \mu\{\mathrm{b}, \mathrm{c}\}=0.829454 \\
& \mu\{\mathrm{b}, \mathrm{c}, \mathrm{d}\}=0.946553 \\
& \mu\{\mathrm{b}, \mathrm{d}\}=0.584926 \\
& \mu\{\mathrm{c}\}=0.6289 \\
& \mu\{\mathrm{c}, \mathrm{d}\}=0.788941 \\
& \mu\{\mathrm{d}\}=0.2947
\end{aligned}
$$

Based on the formula (4) we can calculate Shapley values for all four variables:

$$
\varphi_{a}(\mu, X)=0,07463, \varphi_{b}(\mu, X)=0,14866, \varphi_{c}(\mu, X)=0,29911, \varphi_{d}(\mu, X)=0,1136 .
$$

We see that the third variable has the greatest Shapley value. Finally, by the Shapley's value the customer capital component that represents company's commercial activities with the coefficient of 0.29911 has the greatest importance. On the other side, the lowest importance has the structural capital component that represents value coming from research and development expenses with the coefficient of 0.07463 .

\section{CONCLUSIONS}

Intellectual capital is the main value driver within a company, with a combined use of its three components: human capital, structural capital and customer capital. The intellectual capital leads to positive results only with synchronized use of these three main components. The purpose of our research was to examine the level ofimportance of each intellectual capital component for 498 French companies. The importance of each intellectual capital component represents its contribution in the final performance of a company.

The paper was based on two quantitative methods that relied on the analysis of financial information of companies: Lambda monotone measure method and Shapley's Value method. Our paper is different with respect to the existing literature by conducting a quanti-statistical analysis of disclosure practices, based on a sample of French companies, without any previous selection by sector. 
The results of empirical analysis of 498 French companies were used to fill the gap in the literature about the estimation of intellectual capital components importance. Our results may have important implications to companies' decision making processes. While the current managements seek to improve their financial performance with a high level of risks and uncertainty, the findings from this paper suggest that investments in a particular component can even enhance company's higher financial performance by reducing risks in the managerial investment decisions. This research suggests that managers should pay more attention to the structural component of intellectual capital because it has the highest coefficient of contribution. The role of the particular intellectual capital component forces a more intensive use it in the future value creation processes.

\section{ACKNOWLEDGEMENT}

The first author is supported by the project on Artificial Intelligence ATLAS (grant No. 6524105) by the Science Fund of the Republic Serbia.

We would like to thank the reviewers for their valuable suggestions that resulted in the improvements of our paper.

\section{REFERENCES}

Belo, F., Linc, X., \& Vitorino, M.A. (2014). Brand capital and firm value. Review of Economic Dynamics, 17(1), 150-169. https://doi.org/10.1016/j.red.2013.05.001

Chang, W. S. (2013). Are R\&D and intellectual property rights related to the firms' financial performance? The perspectives on intellectual capital. International Journal of Technology, Policy and Management, 13(3), 245-260. https://doi.org/10.1504/IJTPM.2013.054846

Chu, S. K. W., Chan, K. H., Yu, K. Y., Ng, H. T., \& Wong, W. K. (2011). An Empirical Study of the Impact of Intellectual Capital on Business Performance. Journal of Information \& Knowledge Management, 10(01), 11-21. https://doi.org/10.1142/S0219649211002791

Ciprian, G. G., Valentin, R., Mădălina, G. (I) A., \& Lucia, V. (V) M. (2012). From Visible to Hidden Intangible Assets. Procedia - Social and Behavioral Sciences, 62, 682-688. https://doi.org/10.1016/j.sbspro.2012.09.116

Corrado, C., Haskel, J., Jona-Lasinio, C., \& Iommi, M. (2012). Intangible Capital and Growth in Advanced Economies: Measurement Methods and Comparative Results. IZA Discussion Paper, 6733.

Díaz-Fernández, M. C., González-Rodríguez, M. R., \& Simonetti, B. (2015). Top management team’s intellectual capital and firm performance. European Management Journal, 33(5), 322-331. https://doi.org/10.1016/j.emj.2015.03.004

Diez, J. M., Ochoa, M. L., Prieto, M. B., \& Santidrian, A. (2010). Intellectual capital and value creation in Spanish firms. Journal of Intellectual Capital, 11(3), 348-367. https://doi.org/10.1108/14691931011064581

Dumay, J. C. (2012). Grand theories as barriers to using IC concepts. Journal of Intellectual Capital, 13(1), 4-15. https://doi.org/10.1108/14691931211196187

Francis, J., \& Schipper, K. (1999). Have Financial Statements Lost Their Relevance? Journal of Accounting Research, 37 (2), 319-352. https://doi.org/10.2307/2491412

Garanina, T., \& Pavlova, J. (2011). Intangible Assets and Value Creation of a Company: Russian and UK Evidence. In G. Turner \& C. Minnone (Eds.) European Conference on Intellectual Capital (pp. 165-175). Nicosia, Cyprus: University of Nicosia.

García-Zambrano, L., Rodríguez-Castellanos, A., \& García-Merino, J. D. (2018). Impact of investments in training and advertising on the market value relevance of a company's intangibles: The effect of the economic crisis in Spain. European Research on Management and Business Economics, 24(1), 27-32. https://doi. org/10.1016/j.iedeen.2017.06.001 
Grabisch, M. (2016). Set Functions, Games and Capacities in Decision Making. Heidelberg, Germany: Springer International Publishing.

Hashim, M. J., Osman, I., \& Alhabshi, S. M. (2015). Effect of Intellectual Capital on Organizational Performance. Procedia - Social and Behavioral Sciences, 211, 207-214. https://doi.org/10.1016/j.sbspro.2015.11.085

Hudson, W. J. (1993). Intellectual Capital: How to Build It, Enhance It, Use It. New York, USA: John Wiley \& Sons.

Jensen, M., Potočnik, K., \& Chaudhry, S. (2020). A mixed-methods study of CEO transformational leadership and firm performance. European Management Journal, 38(6), 836-845. https://doi.org/10/ghp2vz

Lopez, J. I., \& Olivella, V. (2018). The importance of intangible capital for the transmission of financial shocks. Review of Economic Dynamics, 30, 223-238. https://doi.org/10/gfnvv9

Maditinos, D., Chatzoudes, D., Tsairidis, C., \& Theriou, G. (2011). The impact of intellectual capital on firms' market value and financial performance. Journal of Intellectual Capital, 12(1), 132- 151. https://doi. org/10.1108/14691931111097944

Marr, B., \& Moustaghfir, K. (2005). Defining Intellectual Capital: A Three-dimensional Approach. Management Decision, 43 (9), 1114-1128. https://doi.org/10.1108/00251740510626227

Martínez-Torres, M.R. (2006). A Procedure to Design a Structural and Measurement Model of Intellectual Capital: An Exploratory Study. Information \& Management, 43 (5), 617-626. https://doi.org/10.1016/j.im.2006.03.002

McGrattan, E. R. (2020). Intangible capital and measured productivity. Review of Economic Dynamics, 37(Sup 1), S147-S166. https://doi.org/10/ghp2rs

Mehralian, G., Rasekh, H. R., Akhavan, P., \& Sadeh, M. R. (2012). The Impact of Intellectual Capital Efficiency on Market Value: An Empirical Study from Iranian Pharmaceutical Companies. Journal of Intellectual Capital, 13(1), 138-158. https://doi.org/10.1108/14691931211196259

Miles, J. (2011). Análisis del Capital Intelectual de las pequeñas y medianas empresas uruguayas y su impacto en los resultados [Dostoral dissertation]. San Sebastián: Universidad de Deusto.

Molodchik, M. A., Shakina, E. A., \& Bykova, A. A. (2012). Intellectual Capital Transformation Evaluating Model. Journal of Intellectual Capital, 13(4), 444-461. https://doi.org/10.2139/ssrn.2550215

Mura, M., Lettieri, E., Spiller, N., \& Radaelli, G. (2012). Intellectual Capital and Innovative Work Behaviour: Opening the Black Box. International Journal of Engineering Business Management, 4(39), 1-10. https:// doi.org/10.5772/54976

Ognjanovic, J. (2017). Relations of Intellectual Capital Components in Hotel Companies. Industrija, 45(2), 181-196. https://doi.org/10.5937/industrija45-12144

Pap, E. (1995). Null-Additive Set Functions. Heidelberg, Germany: Springer Netherlands.

Piekkola, H. (2011). Intangible capital: The key to growth in Europe. Intereconomics, 46(4): 222-228. https://doi. org/10.1007/s10272-011-0387-2

Pucci, T., Simoni, C., \& Zanni, L. (2015). Measuring the relationship between marketing assets, intellectual capital and firm performance. Journal of Management \& Governance, 19(3), 589- 616. https://doi.org/10.1007/ s10997-013-9278-1

Radivojevic, V., Kahrovic, E., \& Krstic, M. (2019). Population skills as an indicator of European countries' competitiveness in the modern economy. Vojno delo, 71(5), 105-116. https://doi.org/10.5937/vojdelo1905105R

Rodriguez-Castellanos, A., Garcia-Merino, J.D., \& Garcia-Zambrano, L. (2011). Organisational Knowledge, Intangible Resources and Business Performance. Journal of Knowledge Management Practice, 12(2), 1-11.

Sharabati, A. A., Naji Jawad, S., \& Bontis, N. (2010). Intellectual capital and business performance in the pharmaceutical sector of Jordan. Management Decision, 48(1), 105-131. https://doi.org/10.1108/00251741011014481

Soewarno, N., and Tjahjadi, B. (2020). Measures that matter: An empirical investigation of intellectual capital and financial performance of banking firms in Indonesia. Journal of Intellectual Capital, 21(6), 1085-1106. https://doi.org/10/ghp2sd

Sumedrea, S. (2013). Intellectual Capital and Firm Performance: A Dynamic Relationship in Crisis Time. Procedia Economics and Finance, 6, 137-144. https://doi.org/10.1016/S2212-5671(13)00125-1 
Singla, H.K. (2020), Does VAIC affect the profitability and value of real estate and infrastructure firms in India? A panel data investigation. Journal of Intellectual Capital, 21(3), 309-331. https://doi.org/10.1108/JIC-03-2019-0053

Sydler, R., Haefliger, S., \& Pruksa, R. (2014). Measuring intellectual capital with financial figures: Can we predict firm profitability? European Management Journal, 32(2), 244-259. https://doi.org/10.1016/j.emj.2013.01.008

Tanideh, S. (2013). Relationship between innovation capital and intellectual capital with value and financial performance. Life Science, 10(10s), 251-254.

Torra, V., Narukawa, Y., \& Sugeno, M. (2014). Non-Additive Measures. Heidelberg, Germany: Springer International Publishing.

Ulubeyli, S. \& Yorulmaz, D. (2019), Intellectual capital based reputation for market internationalization: The case of engineering consultancy firms, Journal of Intellectual Capital, 21(1), 40-61. https://doi.org/10.1108/ JIC-01-2019-0010

Wang, Z., and Klir, G. (2009). Generalized Measure Theory. New York, USA: Springer US.

Zéghal, D., and Maaloul, A. (2011). The accounting treatment of intangibles - A critical review of the literature. Accounting Forum, 35(4), 262-274. https://doi.org/10.1016/j.accfor.2011.04.003 


\section{MERENJE RASPODELE DOPRINOSA KOMPONENATA INTELEKTUALNOG KAPITALA: FRANCUSKI KONTEKST}

\section{Rezime:}

U ovom radu istražuje se doprinos komponenata intelektualnog kapitala ukupnoj vrednosti intelektualnog kapitala. Ovaj rad je usvojio kvantitativne statističke metode merenja Lambda faze i Šeplijevu vrednost na uzorku od 498 francuskih kompanija u periodu od 2008. do 2016. godine kako bi se procenili najveći i najmanji doprinos komponenata intelektualnog kapitala. Za potrebe ovog istraživanja, zvanične finansijske informacije iz godišnjih izveštaja kompanija preuzete su iz finansijske baze podataka „Point Risk“. Rad se fokusira na dve od tri komponente intelektualnog kapitala: strukturne komponente i komponente kapitala kupaca. Krajnjim rezultatom Šeplijeve vrednosti, komponenta kapitala kupaca, koja predstavlja komercijalne aktivnosti kompanije sa koeficijentom 0,29911, smatra se najvažnijom. Sa druge strane, najmanji značaj ima komponenta strukturnog kapitala koja predstavlja vrednost koja proizlazi iz troškova istraživanja i razvoja sa koeficijentom 0,07463. Ovo istraživanje doprinosi literaturi o naukama o menadžmentu ispitivanjem raspodele doprinosa dve komponente intelektualnog kapitala u godišnjim izveštajima francuskih kompanija.
Ključne reči:

distribucija,

komponente intelektualnog kapitala, doprinos, monotona mera, Šeplijeva vrednost. 